\title{
A Homeless Ghost? European Legal Integration in Search of a Polity
}

VB verfassungsblog.de/a-homeless-ghost-european-legal-integration-in-search-of-a-polity/

Daniel Augenstein Di 6 Dez 2016

Di 6 Dez

2016

A member of the European Parliament recently compared the European Union to an Airbus on autopilot attempting to cross the Alps without taking off the ground. Be it the EU's piecemeal approach to fixing its economic governance post-financial crisis or its inability to speak with one voice in matters of common concern from internal border management to external trade: there is a growing sense of urgency in reforming the EU legal architecture to steer European integration back on course. However, such functional necessities are unlikely to sway the peoples of Europe who - tired of the EU's attempts at technocratic self-rule - increasingly retreat into the homeliness of their nation-states. From the early 'no more' war discourse to the 'no choice' rhetoric of late in governing a Union in crisis, European integration has often been presented as a political inevitability. Yet it appears that the most ambitious modern project of legal and political integration beyond the state has come to a halt - where from here?

\section{Back to the beginnings}

In the mid-1980s, the 'Integration through Law' (ItL) School developed what was to become one of the most influential narratives of European integration ((Cappelletti, Seccombe \& Weiler 1986). ItL viewed law as both an object and agent of integration: while law is a product of the polity, the polity is also to some extent a creature of the law. This mutual conditioning of legal structure and political process explained the concurrent integration of and through law in the European Union. On the one hand, ItL capitalised on the instrumental role of positive law in integrating modern societies characterised by a complex differentiation of functional spheres of social reproduction (politics, economics, culture, etc.). On the other hand, it imbued European legal integration with a broader normative vision of 'convergence' that should lead to the emergence of a common European identity.

ItL's original contribution lay less in pointing to the dual nature of law in integrating modern societies than in reflecting on the implications of this duality for legal integration processes beyond the state (Augenstein: 2011). When the governments of France, Italy, Germany and BENELUX signed the 1957 Treaties of Rome they did not envisage creating an autonomous European legal order. They merely agreed on a set of common rules for intergovernmental cooperation motivated by the enlightened self-interest of the participating states. What drove the early integration process was the creation of a common market that was seen both as an end in itself (reviving Europe's post-war economy) and as a means to the end of political stability (taming political power through economic interdependencies). It fell upon the European Court of Justice (ECJ) to constitutionalise European law by endowing it with a claim to supremacy and direct effect. The ECJ thus laid the foundations of a supranational legal order that transcended the state-based constitutional/international law divide and in the same breath challenged received assumptions about the derivative relationship between positive law and the state.

The combination of supranational legal positivism with the functional imperative of creating a common market propelled Europe's early integration through law. Yet it also sidelined concerns about the democratic credentials of a European polity whose political legitimacy was - following the contractual tradition of international law mainly supplied by the national parliaments of the member states. When further integration efforts were stalled by member states' resistance to surrendering the popular sovereignty and constitutional rights of their peoples, it was again the telos of economic integration - the realisation of the EU's fundamental market freedoms of movement of goods, capital, services, and people - that consolidated the autonomy of the European legal order. At the same time, the lack of political enthusiasm for integrating Europe in a more holistic sense helps to explain the centrality and weakness of positive law in European polity building (Walker: 2005). Supranational legal positivism owes its central role in the broader integration process to the EU's lack of a robust socio-political 
pedigree comparable to those that underpin the production of and compliance with legal norms in the member states. Yet the weakness of its social foundations ('solidarity') and political steering mechanisms ('democracy') that makes EU law central to European integration also renders it precarious. Recurring institutional setbacks of Europe's integration through law coupled with a growing political apathy of its people(s) point to the limitations of the EU legal order in accommodating deep-rooted divisions between the member states and dishearten ItL's dream of convergence.

\section{Keep going}

The 1991 Maastricht Treaty on European Union (TEU) marked the maturation of a European polity that no longer considered legal integration a mere by-product of establishing a common (now called 'internal') market. The TEU built on previous efforts to endow the sui generis European polity with more state-like features in order to "create an ever closer union among the peoples of Europe' (Article 1 TEU). Human rights had already entered the European legal order via their recognition as general principles of Community law by the ECJ - yet another judicial contribution to Europe's integration through law that found its political endorsement in the later adoption of an EU Charter of Fundamental Rights. Maastricht addressed the EU's 'democratic deficit' by further enhancing the powers of the European Parliament and by introducing a European citizenship that was to supplement the four fundamental market freedoms. The incorporation of a subsidiarity principle into the European Treaties aimed at strengthening the rule of law by curbing the EU's 'competence creep' in relation to the Member States.

These institutional reforms pursued a twofold objective: enhancing the EU's own political legitimacy by reaching out to the European citizenry; and curtailing the impacts of EU market integration on the legal and political orders of the member states. As concerns the latter objective, functional spill-overs from the internal market into other policy domains enabled/compelled the European Union (cum member state executives acting through the EU institutions) to extend its regulatory grasp over an increasing range of domestic politics. Had EU law once been praised for its 'civilising' mission in taming the national self-interest with a new discipline (Weiler 1999: 350), more recent critiques lament the technocratic and neoliberal facets of an integration process that transforms the European polity into a gigantesque shopping mall for the wealthy and healthy. Externally, successive waves of enlargement led to a territorial expansion of the EU's acquis communautaire, while also raising new challenges to ItL's capacity in generating civic solidarity and social cohesion among the peoples of Europe. The spectre of Turkey's accession - an otherwise useful alley in trading goods and securing the EU's external borders (against refugees) - is a case in point.

As concerns the former objective (enhancing the EU's political legitimacy), these developments nurtured a debate about the 'finalité' (the envisaged endpoint) of European integration and triggered a renewed interest in the constitutional fate of the European polity inspired by ItL's 'federal idea'. Should EU supranationalism be pruned into intergovernmental cooperation in a confederation of states or should the European Union instead reinvent itself as a federal state? In 2001, the Laeken European Council convened a Convention on the Future of Europe that two years later presented a Draft Constitutional Treaty for the European Union. The treaty was endorsed by all member state governments yet failed to garner the necessary support of French and Dutch voters in national referenda. ItL instead proceeded through the constitutional backdoor as many changes envisaged by the Draft Constitutional Treaty found their way into EU law via the 2009 Treaty of Lisbon. At the same time, the EU's elapsed constitutional moment cast further doubts on the viability of supranational legal positivism in creating 'an ever closer union among the peoples of Europe'.

\section{From disintegration to crisis}

The maturation of the European polity went hand in hand with increasing signs of legal disintegration. Firstly, the implementation of 'differentiated integration' in a 'multi-speed' Europe parcelled out the unitary space that EU law was meant to integrate: the Euro-'zone' circumscribed by the common currency of its nineteen members and the Schengen 'area' without passport and border controls that comprises twenty-two member states and four nonmember states. Secondly, ItL became rivalled by narratives of constitutional pluralism that more readily acknowledged the heterarchy of Europe's constitutional landscape and the irresolvability of conflicts of (ultimate) authority between the EU and its member states (Avbelj \& Komarek 2012). Not only did this inject competing 
(national) conceptions of the 'good life' into an EU legal order whose substantive unity and efficacy had long been ring-fenced by the internal market. Constitutional conflicts between different sites of (EU and member state) legal authority also, and thirdly, pushed for 'softer' modes of legal integration such as the Open Method of Coordination (OMC). The OMC pursues Europe's integration of law through flexible standards, negotiable goals, iterative benchmarking and mutual learning processes - features that sit uneasy with more traditional (statist) accounts of the role of law in subjecting human conduct to the governance of rules.

Notwithstanding recurring appeals to Europe's shared value basis (be it its common Judeo-Christian heritage or its history of violent religious and nationalist conflict) and demands that the European citizenry develop a 'patriotic' attitude towards EU constitutionalism: the European Union appears overburdened by the political responsibility that comes with its attempts at managing the more recent waves of 'crises'. The rather brutal austerity measures imposed on member states in economic hardship to save the common currency have not only created new cleavages between 'North' and 'South'. They also perpetuate the EU's long-standing prioritisation of negative integration (removing market barriers) and output legitimacy (delivering growth) over developing integrated economic and fiscal policies - domains still jealously guarded by the member states. While the recent influx of refugees proves to the necessity of closer cooperation in patrolling the EU's external borders, the legal framework governing people's whereabouts inside the 'Fortress Europe' has meanwhile collapsed owing to a lack of mutual trust and assistance between the member states. The EU membership crisis instead signals a revival of national self-interest. Following a popular vote to leave the Union, the UK's 'Brexit' is to re-domesticate its laws and to close its borders to foreign workers. Euroscepticism and nationalism are on the rise in the majority of member states, in some cases (Hungary and more recently Poland) accompanied by an open defiance of the European rule of law.

\section{Where from here?}

In response to the legal and political disintegration of the European polity a new justice discourse has emerged that calls for a revival of the European integration project (Kochenov, de Burca \& Williams 2015). Some put their hopes in the political innovations of European supranationalism, such as more participatory and polycentric forms of governance and rulemaking or the decoupling of EU citizenship from national membership. Others draw on broader conceptions of cosmopolitan democracy and see the EU at the political vanguard of counteracting the disempowerment of the state under conditions of globalisation. For these normative visions to gain political traction would require member states and their citizens to transcend the horizon of national self-interest and view themselves as participants in a public debate centred on questions of common European concern. Recent developments instead suggest a resurgence of national parochialism that presents Europe's governments with the bill for decades of 'putting up' their domestic politics by 'putting down' the European institutions.

Margaret Thatcher once ranked European unity among those utopian ideas that pose a grave threat to freedom. While the final verdict on the freedom-generating capacity of the European Union may still be out, the trajectory of its evolution makes clear that a return to the nation-state offers no plausible solution to today's predicaments of European integration. With historical hindsight, ItL's vision of 'convergence' overtaxed the capacity of supranational legal positivism in integrating European societies - at the expense of demystifying the (violent and hegemonic) history of European nation-building and exploring more pluralistic modes of living together under a common rule of law. At the same time, the new-old populism that now dominates domestic politics and that purports to free national democracy from the clutches of Brussels' bureaucracy has lend itself to increasingly authoritarian interpretations of 'home rule' in a number of member states. This betrays the liberal ambitions of the early European legal integration project which in consolidating the common market also aimed at emancipating the citizen from the state. It moreover ignores that the EU's transition from economic policy to constitutional polity was an attempt to respond politically to the expansionist impacts of market integration on member state democracies. Europe's retreat into a Rawlsian-type internationalism will do little to redress the imbalance between the limited room of manoeuvre that member state governments still enjoy 'at home' and their extensive powers to govern the EU 'from abroad'. It will contribute even less to creating the political conditions for weathering the challenges of economic globalisation in the late days of European welfare state paternalism.

Forget about hymns and anthems - time is ripe for a new political pragmatism that desists from playing off the 
European Union against the Member States. However convenient and 'popular' such blaming and shaming may be, it is simplistic and disingenuous all the same. The political choices ahead are of a different kind: more free trade for unfree people or a reinforced effort to design democratically accountable legal institutions beyond the state. In the latter regard, the 'homeless ghost' of EU law has fared better than any of its global competitors.

\section{References:}

Augenstein, D. (ed.), 'Integration through Law' Revisited: The Making of the European Polity (Ashgate: 2012).

Avbelj, M. \& Komarek, J. (eds.), Constitutional Pluralism in the European Union and Beyond (Hart: 2012).

Cappelletti, M., Seccombe, M. \& Weiler, J., 'Integration through Law: Europe and the American Federal Experience', in M. Cappelletti, M. Seccombe \& J. Weiler (eds.), Integration through Law, Vol. 1, Book 1, 3-68 (de Gruyter: 1986).

Kochenov, D., de Burca, G. \& Williams, A. (eds.), Europe’s Justice Deficit? (Hart: 2015).

Walker, N., 'Legal Theory and the European Union: A $25^{\text {th }}$ Anniversary Essay', 25(4) Oxford Journal of Legal Studies (2005) 581-601.

Weiler, J., The Constitution of Europe (Cambridge University Press: 1999).

\section{LICENSED UNDER CC BY NC ND}

SUGGESTED CITATION Augenstein, Daniel: A Homeless Ghost? European Legal Integration in Search of a Polity, VerfBlog, 2016/12/06, http://verfassungsblog.de/a-homeless-ghost-european-legal-integration-in-searchof-a-polity/. 